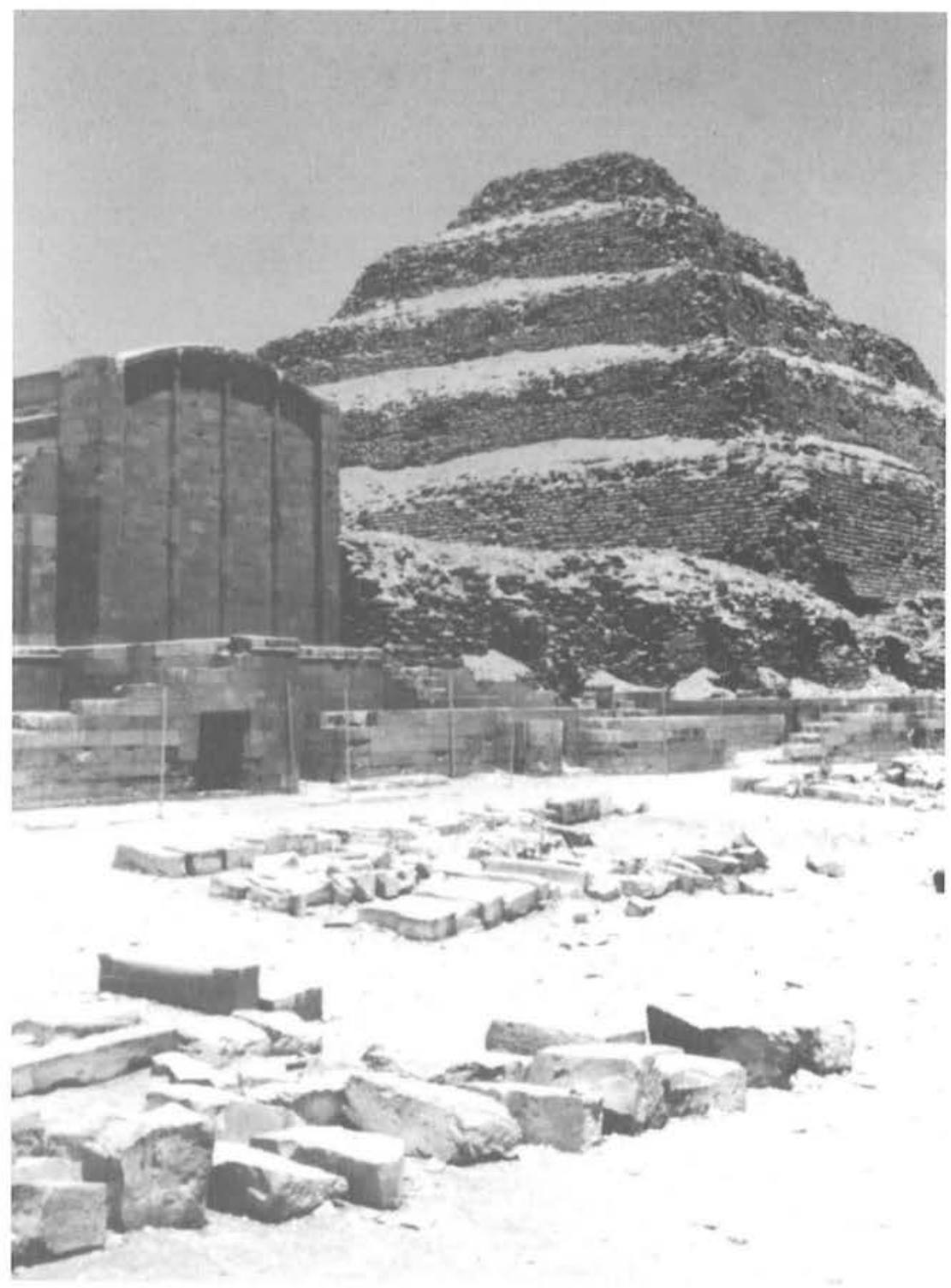

Reconstruction work in progress-The Djoser complex, Saqqara, Egypt. 


\title{
An Architectural Metaphor: the Destining of Imhotep Stone
}

\author{
Michael Linzey
}

Imhotep stone is an original figure of architectural duplicity. Imhotep, 'He who comes in peace,' was the name of the first historical architect. It was also the name, through a long Egyptian tradition, for a fine white limestone in which much Egyptian architecture, and Imhotep's own architectural work in particular, was dressed. The name doubly indicates the human subject and the material object of an original classical architecture. The Djoser funerary complex at Saqqara was an Old Kingdom expression of the politics of death; yet it endlessly imitated the forms and materials of archaic houses for the living. The white stone of Imhotep dominated the western horizon of the city of Memphis 'for the span of Eternal Sameness,' and eventually eclipsed altogether with stone that city built on mud, so that 'city' and 'stone' became almost synonymous names for the progressive kind of architecture of western civilisation. Compared to the 'honest' modern materials, like concrete, steel, glass, and plastic, which promise nothing, which are true only to their own technological ideal, which present 
themselves as if they were devoid of political, aesthetic or mythical agendas, unadorned, ahistorical, demanding neither to be conserved nor vandalised, Imhotep stone is the 'falsework' of a traditional architecture, civilisation, culture. An original figure of duplicity. This metaphorical duplicity that pervades Imhotep's house of stone, these double figures, are a future promise perhaps of an archaic meaning that has so far eluded a theory of architecture.

The proper-ness and connectedness (and the duplicity) of the 'house of stone' is deeply rooted in language. The word 'masonry' carries the same double meaning. It means house, maison in French, mansion. It is also the name of one particular method of building houses (and funerary monuments.) It is the measure and means by which a mason sets out lines to dominate the earth, to make a house of stone. The root, $m a-$, which is also heard in measure, mathematics, map, and the making of the mansion, may be traced to the Sanskrit where ma means setting out the straight foundations for a building, and maya means a kind of illusion or dream that appears as a fabrication architected upon the 'true reality'. For summary purposes, we designate this metaphor which Imhotep 'coined' for architecture, and possibly for the first time, "The masonry of masonry."

In ancient Egypt the Pharaoh was called the 'Great Mansion', domain and dominion of the God-King. His (or her) 'house' of stone was the duplex seat both of domestication and domination. The stone funerary complex of King Djoser ${ }^{3}$ is estimated to have been built about the year 2,680 B.C. In the entrance colonnade of this funerary complex, the stone columns or wall-endings are over-sized, and carved to look like bundles of reeds. It appears stone was dressed in this way to imitate a traditional or archaic form of domestic construction with bundled reed columns. But this 'imitation' was not simply a linear 'copying' of an older exemplary architecture. It represents a domestic material expressed in stone. At the same time, by the majestic girth and regal stature of the attached columns, the masonry also betokens the power of Djoser, the domination by his united kingdom of North and South Egypt over the 'nine bows' of his traditional enemies. Domination and domestication, is a 
perennial double figure of stone architecture, an architectural metaphor which now calls to us out of language itself.

At the beginning of stone masonry, already the capitals of columns were a preferred location for duplicity. To embellish a column at its capital is to make light of the roof. There is visual humour in this expression of contrast between effort and repose, between vertical order and horizontal stratification, between the stress and strain in the heavy masonry and the lightness and repose of a limpid papyrus flower, between the demand for civil obedience and the free weediness of a leafy plant. A political message is not hard to find here. A subject people who dwell in the house of stone must

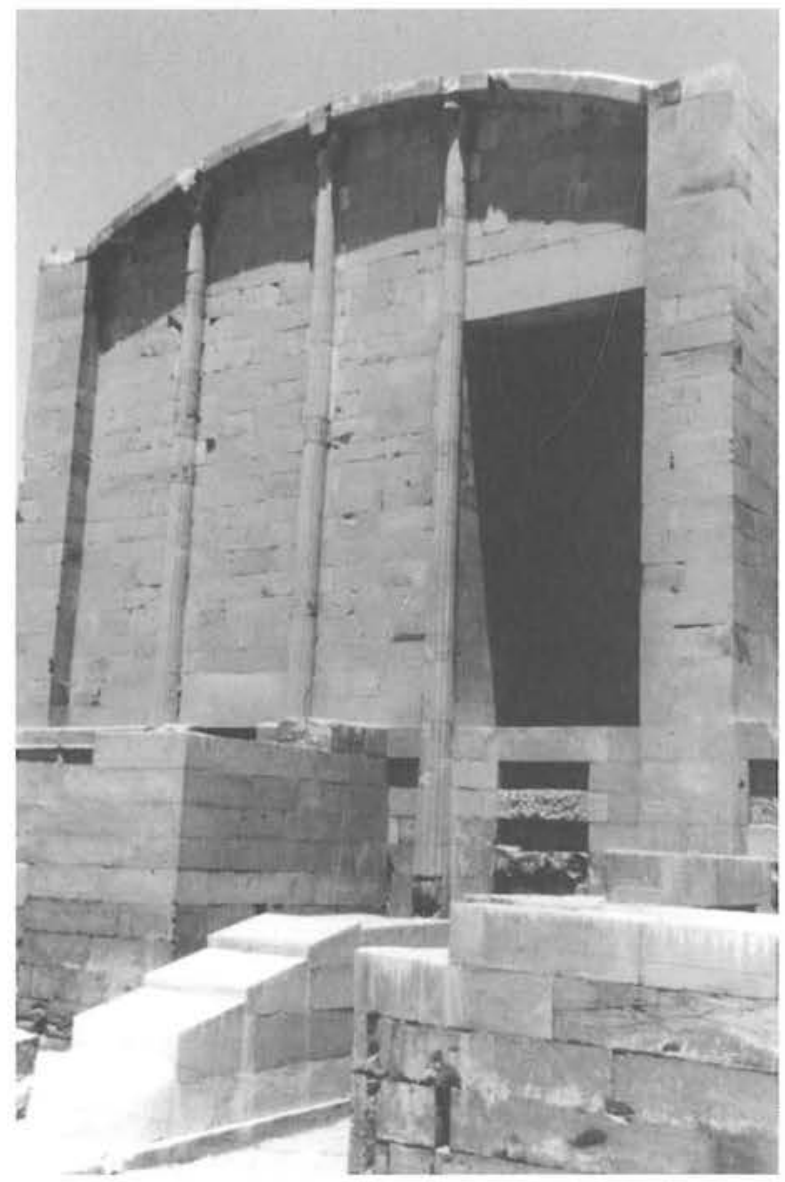
also bear the yoke of domination lightly, and with stony good humour, if they wish to live under the domain of the king, if they would subject themselves to the royal justice, called ma-et.

If the Djoser complex were built today we would describe it not only as duplicitous, but as fake, imitation, even unauthentic. Take for example its doors and gateways. The complex, covering 15 hectares, was surrounded by a 10 metre high stone wall with fourteen gateways. But only one of the gateways was an actual entrance-way for the living. The other thirteen entrances were imitation, entrances only in the imagination. To try to insist that there might 
have been some practical function for this fakery-that the imitation entrances were to deceive grave-robbers for example-is to lamely seek for a continuity of purpose between ancient Egypt and today which the evidence cannot support. Throughout the complex, stone fake doors were carved in walls, open doors which led nowhere and closed doors which indicated but prohibited entry. Stone imitation doors complete with imitation stone hinges stand ajar for eternity. What possible meaning could there be for all this unauthentic duplicity?

The duplicity of Imhotep stone may have been built on a cosmic doubleness. We may be reencountering in it the long-ago twin gods, Tefnut and Shu, whose respective activities were designated in the texts of the day in terms of Eternal Sameness and Eternal Recurrence. If we compare this duplicitous Godhead with the modern nihilism, the singular god of 'Eternal Progress' in our own time, we may be persuaded that the thought processes of Imhotep the architect were more 'attuned' to duplicity than the reductive, object-oriented patterns of rational thought allow us today. But the thought processes of Imhotep also remain a closed door to a theory of architecture.

What can be more valuable and achievable than to speculate about subjective intentions is to see the course of western architecture itself through the duplicity of Imhotep stone, to trace the historical destining of its metaphor. All architecture suffers duplicity similar to the duplicity of Imhotep stone, (suffers from it also, bears with it, and likewise bares itself to it.) Stone architecture perhaps more than any other, is heroic in this respect in its barefaced deceit.

\section{Metaphor in a Theory of Architecture}

Having emphasised the aspect of metaphor as duplicity, I want to turn now to its aspect of 
propriety in a theory of architecture. If a house is dressed up in stone to look like a rush and clay and wooden house, (or if a business house is dressed in the sacrificial ornaments of a stone temple,) this ought to be seen as improper, dishonest, duplicitous, even a foolish thing for an architect to do. Yet the house of stone is also, at the same time, the epitome of civilised architecture in western culture. 'The masonry of masonry' is a gross impropriety, a societal duplicity. Yet by the same token it is the proper property of western architecture. And when a figure is valued and used, when it is a valued property of a community, its original impropriety, the effect of its metaphorical beginning in duplicity, can be erased from memory, we can become oblivious to it, so we don't even think of a stone house any more as a metaphor.

But the proper architectural 'text' can and should be 'read' in terms of metaphor, not because architecture 'copies something that properly belongs to something else,'-in the sense, for example, that the limestone boundary walls of Djoser's funerary complex improperly copy the 'real' palace walls which 'rightfully' belonged at Memphis, but which presumably were made of mud, not because all architecture in a sense copies all previous architecture. Metaphor is proper in a theory of architecture because, further than this, (and in another sense which is also Aristotelean,) architecture uses metaphor to 'make one see things,' to represent things 'as in a state of activity.' If architecture is to have a theoretical life of its own, it is necessary to theorise metaphorising thinking along with idealising thinking. Here we are guided by Ricoeur's radical treatment in the tradition of Heidegger of the duplicitous logic of metaphorising thinking as a proper alternative to idealising thinking ${ }^{4}$. Ricoeur notes that although mimesis is usually understood to mean 'imitation', one thing imitating another thing, yet this weak form of correspondence was not the full original meaning understood by Aristotle. Mimesis describes the way that poetic language 'expresses existence as alive.' Metaphor is a language construct which 'makes one see things because it represents things as in a state of activity. ${ }^{\prime 5}$ Here Ricoeur is quoting Aristotle's Rhetoric. We should ask why 
Aristotle discerned no fundamental conflict or difficulty in equating 'the imitation of nature' and the structured 'enlivenment' of a poetic text. 'Perhaps,' suggests Ricoeur, 'it is because, for [the Greeks] nature itself is living

To 'enliven' the text of Imhotep stone with a theory of metaphorising thinking is not meant in the sense of 'opening the mouth' of the life-sized stone image of the living god, the Horus Neterkhet Djoser, who, dressed in his heb-sed robes, once sat on his throne north of the wall of his pyramid. This stone sculpture, now deposited in the front foyer of the Cairo Museum, was once enclosed in a stone serdab or cellar at $e^{2}$ base of the step-pyramid within the Djoser funerary complex at Saqgara, completely hidden from view. Only two tiny eye-holes had been drilled in the stone wall of the cellar to provide a glimmering of communication with the world of the living, through which two quartzite 'eyes' could stare at the northern horizon for the span of eternity. In ancient Egypt a ceremonial used to be performed on stone figures, known as 'open the mouth.' But while we can acknowledge the abundant strangeness implied by this practice, we are more inclined to enliven Imhotep stone as a metaphor for architecture history and theory, to reveal the life of architecture in its state of activity, to read the lively Geschichte of its destining.

What unlikely conjunction of names and events legislated the 'house of stone'? Why did Imhotep make the divine imperial 'house' of Egypt in the image of stone? What was this architectural propriety in its original metaphorical impropriety? Why did 'house' and 'stone' remain conjoined in an indissoluble structure, a masonic fixity, an historical propriety, until the modern era of technology? And why in the modern era did stone masonry suddenly become 'dis-honest' once more? These are proper questions to ask with respect to the history of a metaphor in the context of a theory of architecture.

Metaphorising thinking is a proper way to think abott architecture. Idealising thinking is Djoser properly the property of philosophy. Wigley' makes this very important observation, which 


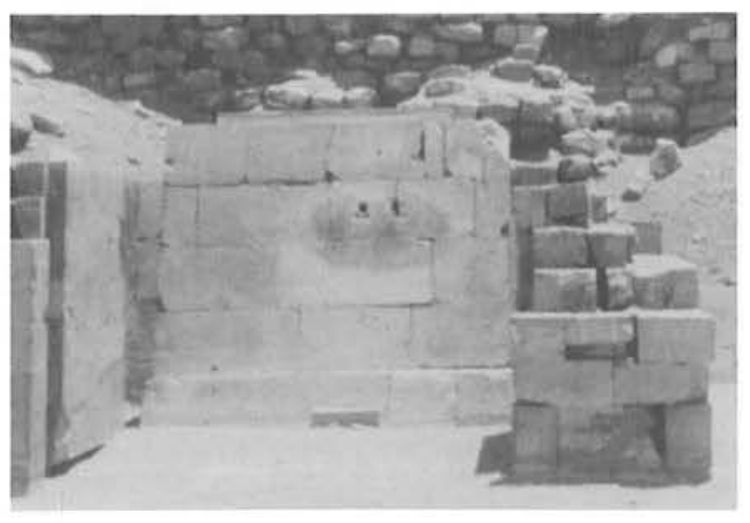

The serdab of Djoser.

breaks the ground for a truly autonomous theory of architecture, relocates the boundary between theory and philosophy, a professional division of interests. When philosophers like Plato and Kant secretly coerced metaphorical constructions into the text of philosophy, when philosophers like Heidegger and Derrida employ architectural metaphors as they embark on the deconstruction of traditions of idealised thought, we should say that they are properly doing architecture. Philosophy constructs edifices of idealised thought for purposes of edification. But when philosophy 'descends' to metaphor, it cannot any longer make this claim for edification, the clarification of thought, because metaphor can only edify its own edifice- the texts of every single philosopher, from Plato and Aristotle to Heidegger and Derrida, explicitly affirm and reaffirm this. Metaphor is repeatedly (and properly) judged to be improper in the text of philosophy. A metaphor in the text of philosophy can only be an edifice constructed for its own sake, a vanity. But this 'construction for its own sake,' which is improper in philosophy, is the property and the proper edifice of an autonomous theory of architecture. This is Wigley's argument as I understand it.

Metaphorical duplicity is proper for architecture but improper for philosophy. Yet all philosophers at one time or another have secretly stooped to this philosophical impropriety. Plato 'descended' to metaphor-like duplicity when he invented 'The idea of the idea.' Heidegger ${ }^{7}$ remarks that Plato committed an extreme violence upon the Greek language, violated its propriety, duped its language community, when he used eidos to mean 'that which in each particular thing endures as presence.' For eidos in the common speech of Plato's day correctly meant appearance, 'the outward aspect that a visible thing offers to the physical eye.' Plato exacted of this word 'something utterly extraordinary,' remarks Heidegger: 'that it name what precisely is not, and never will be perceivable with physical eyes.' Plato 
originally and duplicitously violated the meaning of the word idea to make it mean 'the nonsensuous aspect of what is physically visible,' whereas it properly and ordinarily names and is, 'that which constitutes the essence in the audible, the tastable, the tactile, in everything that is in any way accessible.' And it was upon this extraordinarily fertile but highly improper conjunction of names, this metaphor, 'The idea of the idea,' that Plato proceeded to 'architect' an 'edifice' of idealised thought. Idealising thinking became the 'clear ground', the unspoken 'dwelling-place' of western metaphysics. There is no space here to speculate what acute historical and cultural nexus or turmoil might have provoked this new metaphor, this architecture, from the pen of Plato. But this 'pyramid' of western metaphysics was built on shifting sand, not on the solid ground of the literal use of Greek language. It was built on a metaphorical duplicity.

Fissures of metaphorising thinking are like $Y$-shaped scratch-marks embedded in the petrified stratifications of history. Two unlikely thoughts are drawn together at some moment in history, by some individual of genius who gives one of them a name that 'properly' belongs to the other. In subsequent history the two act as one thing in the public imagination, and become as if they had always been united. This new-found and consequential unity of a metaphor is its destining propriety. But it derives from an initial act of gross impropriety, societal duplicity, architecture, in which a metaphor is first coined, con-joined. Once, a Yshaped algebra of metaphor in the shape of a stone house also structured and informed a theory of architecture. Two lexicalised metaphors, expressed as the tautologies they have become: 'The masonry of masonry,' and 'The idea of the idea,' are equivalently architecture, like single words in a language, tokens of comparable value in a language of metaphorising thinking, as if Imhotep and Plato were equivalently architects in the fabrication of Western cultural reality.

Extending the terms of this edificatory metaphor slightly, we remark that the ultimate idealisation in the Western project of idealising thinking was to represent 'the whole' of reality 
in the image of a perfect block of stone, ashlar, whole, absolute, ultimate, indissoluble, and founded on necessity; we disclose the 'architecture' of western thought 'as a whole,' from Plato to Kant. But even reality is socially constructed; even this perfect stone of metaphysics is a construction. The traces on the ashlar surface, the tiniest fissures of metaphor, are remnant marks of morphology on the idealised language of edification. To retrace these fissures, to locate them at all in philosophy is to deconstruct the philosophical project of idealisation, which has been Heidegger's and Derrida's project. Deconstruction reveals, not only that the ideal reality is constructed in this or that particular detail, but that the edifices of idealising thought itself are constructed out of and grounded upon metaphorical figures. The texts of western realism dwell in and on a con-text of architecture. But if metaphor is improper in the text of philosophy, and always understood to be a blemish and a defect which ought to be ground off the surface of the perfect block, yet to locate and disclose duplicitous fissures on the surface of the house of stone is to open the theory of architecture as properly a theory of metaphorising thinking. Metaphor is a trope of place and displacement. The proper place of theory is architecture.

This kind of 'secret history of a word' is a property of all words in metaphorised language, and all language is metaphorised. To suggest that all language is therefore architecture would bring a radical meaning to Heidegger's famous metaphor, 'Language is the house of Being.' Heidegger not only sets 'language' in a state of activity; architecture also is activated. Already released from its archaic technology, the house of stone, and now from the granite tyranny of idealising thinking, architecture is free to rediscover its postmodern propriety as 'poetry's innermost site.'8

\section{Petrification of the Subject}

The course of history, Vattimo ${ }^{9}$ has remarked, is neither degenerating nor advancing, neither a progress nor a decadence. There is no secret narrative, not entropy, not evolution, not 
decline, not ascent. Imhotep was not a Giant any more than he was a savage (although he was a Noble.) He was an architect of the first water, and he deserves critical attention on this ground alone. Imhotep opened a field of possibility for architecture by designing a first extensive work in dressed stone, stone art at the scale of dwelling, the material of Eternal Sameness posing, imitating, moving in the world of Eternal Recurrence. Imhotep made stone the subject of architecture, transformed the intractable underground worthlessness of stone and made it the lingua franca of civilised being. But within this stony-faced nihilism of history, changes have occurred specifically in terms of the architectural meaning of Imhotep stone. Whereas '... we become capable of playing those language games which constitute our existence upon the sole basis of our belonging to a particular historical tradition, in the same way in which we feel respect for monuments, graves, traces of past life ... , , ${ }^{10}$ yet simply belonging in the architectural tradition of Imhotep does not seem to be enough to cause us to comprehend, respect, embrace, imitate his monument. Even accepting that Imhotep stone is the 'true origin' of architecture, that Imhotep's language of stone 'constitutes our existence' as architects within a long tradition, yet it seems we are not able (not able any longer, not yet able) to play the language game whereby Imhotep stone was itself constituted. In brief, the original and lively propriety/duplicity of the architectural metaphor, "The masonry of masonry,' has to be separated from a blocking effect, a petrification of the subject of architecture, attributable to the crypto-architecture of western realism, attributable in particular to a metaphor of architecture which Plato insinuated into the text of philosophy, "The idea of the idea.'

But is it possible to think the 'Petrification of the Subject' in an archaic reading, untrammelled by Platonic philosophy, prior to the Cartesian appropriation of the Subject into the interior of the being of ego cogito, think Imhotep stone independently of 'The idea of the idea' and its consequential destining, in any 'original' sense or appreciation of it?

This thinking is different from the figuration of the pyramids in the texts of Hegel, Foucault 
and Derrida. In the postmodern reading an archaic Subject is felt to have been lost or killed or petrified with age, with time, or stoned to death by history ${ }^{11}$, by impact with the west, by metaphysics, by technology. It is as if an excess of pressure had been generated in the interior of Imhotep stone, as if Imhotep himself expelled the 'subject' of his king out of the body of his own tomb. Was Djoser the king thus 'evicted' by Imhotep, forced to vacate his stony property, set upon and challenged forth in the ordering of the orderable, into dual and separate abodes in the deep pit beneath the pyramid and in the sky above, into different realms of body and soul, heaven and earth, metaphor and metaphysics? Was the pyramid thenceforth (in other words, was architecture from the beginning of stone architecture,) only a hoarding sign nailed to an empty house? Was the 'life' of architecture squeezed and compressed to a mere abstract point in plan, or a vertical line in elevation at the centre of an immense accumulation of stone, to only a token of abstract geometry, a vector of indication?

Two interpretations of Imhotep stone can be read in the conjunction of 'house' and 'stone': that the proto-architecture is a house properly understood, a place built of stone for the subject of the dead king to dwell within; and secondly, that the pyramid is a storehouse, a 'standing-reserve' of stone, a house of stone for stone to dwell. This second reading signifies in Heidegger's text as 'the advent of technology.' 12

The differences between these metaphorical readings of an architectural work are drawn here not to disprove, disqualify or falsify one or the other, nor to demonstrate that architecture cannot sustain a single consistent meaning, but to show the historical turning of the destining of a living metaphor. There was a time when stone was the proper architecture of civilisation, and the appropriate medium in which to express domination and domestication through the figuration of domus. This historical destining of stone is divisible in two parts. First was the time of Imhotep stone, prior to 'The idea of the idea,' and therefore, we will seek a reading of it that is independent of Platonist ideation. The second interval was 
the time of the Masons, the destining of the 'absolute ashlar.' Between and within these intervals, the expression of stone architecture underwent profound changes. Yet throughout its whole destining, the petrified subject itself of architecture, this metaphor, Imhotep stone, lying for the most part buried beneath the sand at Saqqara, was essentially unchanged.

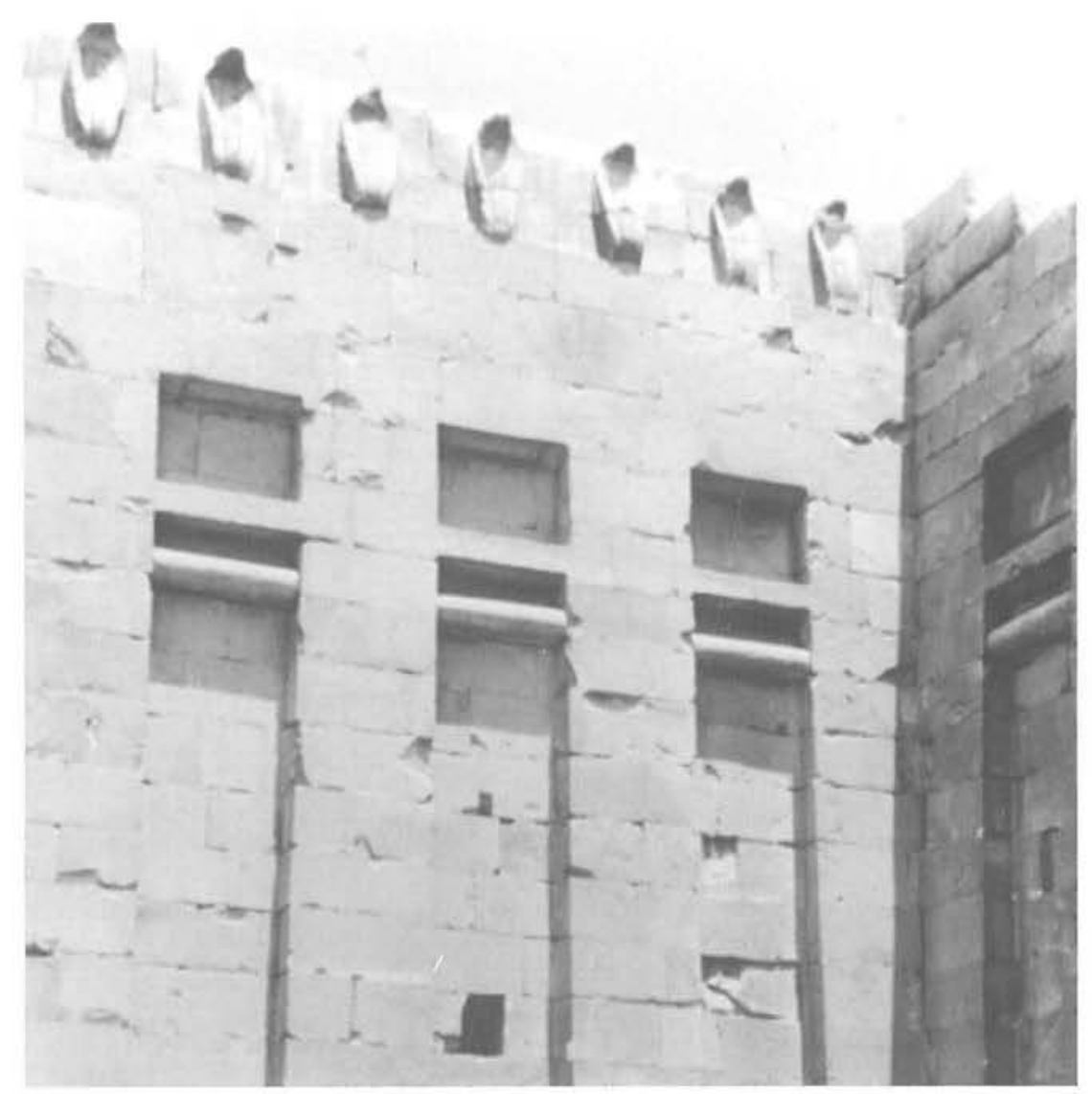

The situation is further obscured by the longevity of stone architecture. Architecture regularly outlives its own time. It naturally outlasts the time when its metaphorical duplicity is evident to all (as lively relevance, as controversy), survives into the era of apparent singularity/propriety (sometimes but not always of meaninglessness). Architecture also regularly imitates exemplars that are thus dislocated in time, that no longer are what they once appeared to be, whose former meaning is beyond recall. The text of architecture is usually misread in this fashion by architects systematically and as a matter of course. Theories of architecture which represent history as some orderly progression of an idea or a progressive series of ideas, or history by a comparative method that describes works of architecture as unequivocal cultural and geographically specific idealised objects, are misled by the essential volatility of the metaphorical subject matter. Theory requires to treat metaphors rather than objects as the proper units of architecture, or more precisely as 'duplets', units of difference.

A first reading of the petrification of the subject can be reconstructed in terms of what 
historians today call the politics of death. In a culture that is ruled by a living god, as Ancient Egypt was ruled for many centuries, the politics of death can exert a volatile and disruptive effect on the public imagination. Ebersole ${ }^{13}$ has pointed out that although death itself is a 'given', a 'biological fact', yet its meaning is always open to be socially negotiated. Whenever a king dies or a national leadership changes hands, this is always a propitious time for political manoeuvring. When the king is also a god, his death can seem to put more at risk, can sometimes call for recreating and reforming the whole of cultural cosmology.

When the king died in the Old Kingdom of Egypt, the remains were returned to the mothergoddess, Nut. This metaphorical return at the time of death was a necessary ceremonial to restore the balance of life, which was understood by the Egyptians to be a cycle of Eternal Recurrence. Born of woman, the king returns at death to the body of a woman. This funerary intention is clearly stated in the following Pyramid Text:

You are given to your mother, Nut, in her identity of the coffin. She has gathered you up, in her identity of the sarcophagus. You ascend to her in her identity of the tomb.

To the modern mind Nut is usually identified with the sky. The sky is unavoidably implicated by association with the metaphysical realm, supra-terrestrial, distinctively beyond the earth. It can be surprising therefore to hear that the goddess 'of the sky' is identified as a primal architecture 'of the earth,' a nesting of enclosure within enclosure in the stony forms of mortuary architecture. The modern mind is adept with nested idealisations of the 'real' sun and the 'real' sky, physical realities clearly delineated and apparently singular, so that when we read that 'the $a k h$ ascends to the sky,' it is not immediately apparent that a metaphorical 'sky' is meant, that the $a k h$ ascends into the pyramid itself as its proper abode and dwelling place, there to re-encounter the sky goddess Nut, inside the house of stone. It can 
be a startling displacement, a dislocation of the goddess out of her 'proper' realm, to show

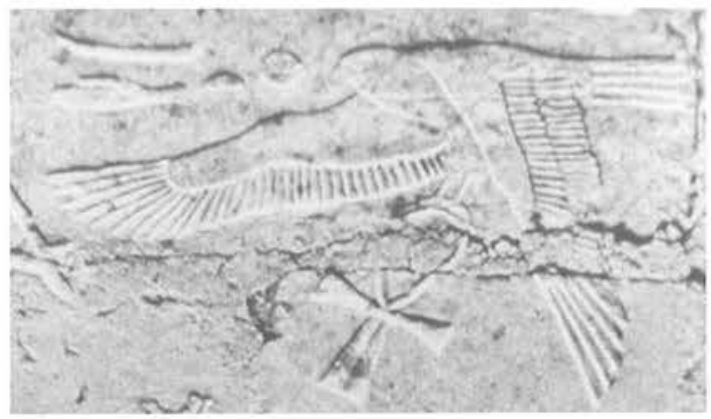
herself as a pyramid on the ground, and as a sarcophagus under the ground. This reading of the funerary mound is not the 'high ground' or 'staircase' for a descending Epiphany of a god, as is more usually assumed. Rather it is an amniotic sac which bears up and protects the King, petrified in his limit, and an architecture which bears up stone into the sky.

The Heliopolitan cosmogony at the time of the Pyramid Texts was headed by an Ennead of nine major gods: Atum, the 'finished creation' who began like an egg floating in the abysmal chaos; his children, Tefnut and Shu, who are the 'air' and the 'dew', but also twin aspects of the 'finished creation', whose respective activities are ascribed the verbs wnn, 'exist' and hpr, 'develop'; Tefnut and Shu conceived two offspring, Geb and Nut, 'earth' and 'sky', who were also the active male and female principles of creation; their own children are Osiris, Isis, Seth, Nephthys, and Horus. Although these Egyptian gods are often represented in the forms of human and animal beings, they are not 'subjective' in the modern sense, not subject to the ego cogito. They are better understood to be metaphorical explanations of the architecture of Being, the constructive and conservative principles of cosmology, always recurring and always the same, in the socially constructed ordering of Egyptian reality.

If the politics of the death of Horus is thought and socially constructed in the double-logical frame of metaphorising thinking, the coffin, sarcophagus and tomb can be potently associated with Nut, mother of Horus. The king's mummified remains are preserved in a coffin within a stone sarcophagus in a deep pit under the ground. Subsequently the king is understood to ascend to a final dwelling-place in a tomb that is constructed over the head of the pit. And in this final dwelling-place, in the swollen body or womb of Nut, it is the king's pleasure that he may 'come and go' as and whenever he pleases: 
The King's lifetime is Eternal Recurrence, his limit is Eternal Sameness. In this his privilege of: "When he likes he acts; when he dislikes he doesn't have to act."

(Pyr. 412 a-b)

There is some evidence that this metaphorical meaning of the lively interiority of pyramid architecture was understood in Egypt at least into the New Kingdom. Ames, son of Iptah, who lived at the time of the 18th Dynasty, wrote an inscription in demotic script on one of the walls of the Djoser complex, which records that he '... came to the temple of Djoser, and it was as if the sky was inside and the sun was risen within .' 15 [The emphasis on interiority is mine.]

Imhotep introduced a novel 'twist' to this social-political metaphor of death and resurrection by constructing the tomb as well as the sarcophagus out of stone. To build a step pyramid and a surrounding complex of imitation buildings, a city for the dead, in stone was a radical departure for architecture, instituting a new material and a new technology; but it was also in many respects a natural extension of the architectural language in terms of metaphorising thinking the identity of Nut. As an architecture of Nut, the step pyramid makes metaphorical sense. The tomb was now of the same material as the sarcophagus, stone the proper material to represent a god. The superior bearing strength, the precise technology of stone called Imhotep to raise the subject of Nut in mighty steps above the walls of the king's enclosure, to publicly reveal the dome-womb-tomb of the mother (and the grand-daughter) of creation. Egypt could now clearly see that Nut 'encloses' the deceased in the same way that the sky encloses the 'known' world of creation, nurtures and protects its creature/ creation from dissolution in the abysmal waters of chaos. The giantism of the step-pyramid reinforces this metaphor of the sky, allows architecture to speak publicly of Nut in her identity as the sky. And the four sides of the pyramid are not oriented to the four horizons of the (real) sky, so much as they metaphorically are these horizons. By architecting Nut in her identity as the stone tomb, Imhotep emphasised the aspect of Eternal Sameness of the 
sky goddess. Stone by its permanence reinforced the metaphorising thinking that the deceased king will remain and dwell in the body of Nut for a very long period of time. The subject of the king too is 'petrified' in stone for the span of Eternal Sameness.

You will cause the King to be sturdy by causing this pyramid of the King and this his construction to be sturdy for the span of Eternal Sameness.'

(Pyr. 1660 a-b)

Within the walls of the Djoser temple Imhotep constructed a stone imitation of an urban complex. He showed that a 'city of the dead' can be a beautiful, habitable place for a dead king to dwell forever. By the same token he raised the petrified image of a new lifestyle for the civilised living subject as well; that a living king and a subject people could equally 'dwell forever' in a city of permanence and precision, provided, dressed and decorated with stone. And the subject of architecture itself was petrified.

But postmodern theorists read a second family of meaning of 'petrification of the subject' in the Egyptian pyramids. Since Napoleon's expedition of 1798 rediscovered the archaic genius of Egyptian stone architecture, fragments and impressions of Imhotep stone were transported into a European intellectual climate in which a revolutionary idealism, coupled with nascent evolutionism, spawned a fervour of mystical free-masonry. The ancient architecture of death and resurrection was vigorously interrogated for its ideological significance. According to Derrida, Hegel wrote specifically about the Egyptian pyramids that they were an historical anticipation of Semiology, the first architectural 'signs' of a modern science of pointing. Hegel understood the pyramids to be pure signs 'undefiled by symbolic participation' in what was signified by them. As signifiers they did not bear an imitative relation to what Hegel believed to be their primary significance, namely the petrification of Geist. Hegel understood that the Sphinx at Giza was an older and more 'primitive' form of expression in stone; it was not yet a 'pure sign' but a 'symbolic' architecture, or not yet architecture but 
sculpture. Its 'animality of spirit' was understood to be still present in the stone, 'asleep in stony sign.' ${ }^{16}$ But the pyramids on the other hand were petrified signs of a departed Subject. Like so many stone arrow-heads, cast aside and forgotten in the desert, that for millennia had pointed to the blue unclouded emptiness of the Egyptian sky, they signified the departure from the earth into an idealised realm of some lost tribe of Spirit.

Derrida, reading Hegel, remarks that the Egyptian pyramids appear to be arbitrary in terms of signification ${ }^{17}$. Although a pyramid as a sign seems to point to the celestial sphere (which Hegel may have presumed to be located above, in the direction of the sky, the direction in which the pyramids are pointed,) yet its 'functional' point was to demark the dead body of the King, which, in the case of the Djoser step-pyramid at least, was once buried in a deep pit beneath the stony monument itself. This 'arbitrariness' in the pointing-sense might be said to mark a first architecture of différance; in that a 'deferral' and 'dislocation' of subjective meaning is indicated through the arbitration of direction of the pyramid-as-sign. Derrida notes that the letter ' $\mathrm{A}$ ' in différance, the silent device in his theoretical deconstruction of Semiology, 'is' a pyramid.

'It is put forward by a silent mark, by a tacit monument, or, one might even say, by a pyramid-keeping in mind not only the capital form of the printed letter but also the passage from Hegel's Encyclopaedia where he compares the body of the sign to an Egyptian pyramid. The A of différance therefore is not heard; it remains silent, secret and discreet, like a tomb.

'It is a tomb that, (provided one knows how to decipher the legend) is not far from signalling the death of the king.' ${ }^{18}$

By this unlikely metaphor Derrida assigns to a letter a name that properly belongs to architecture. He thus signals the beginning of a short but fruitful incursion on his part into the domain of architectural theory. But the 'king' for Derrida, whose 'death' is signalled by the pyramid form is not his friend Peter Eisenman. It is the idealised Subject of modern thought, Hegel's Geist, secreted and petrified at the centre of the project of Semiology. The first stone 
architecture signals for Derrida the finite history and deconstructed 'end' of the arbitration of Semiology. He writes: "The process of the sign has a history and signification is even history comprehended.... An initial index of all this is to be found in an architectonic reading ... ..$^{19}$

Foucault ${ }^{20}$ also returns, metaphorically, to Egypt when he represents the post-modern historical-critical endeavour with respect to the subject, as an 'archaeology'. The philosophical impropriety of 'doing architecture' in the name of edification, is acknowledged, and the proper con-text for thought is diverted instead to the site of archaeology. The modern discipline of history, Foucault writes, is in '... the grip of phenomenology.' (p. 203.) To overcome this phenomenological tenacity the historian should operate more like an archaeologist. It is proper therefore for a Foucaultian theory of architecture, in order to resurrect architecture from the petrifying grip of phenomenology, to invoke the figure of J.-P. Lauer, the French architect who was also diverted from architecture to archaeology, who fossicked for years through the ruins at Saqqara to unearth and reconstruct the buried fragments of architecture of Imhotep stone. Like Foucault, the text of Lauer also '... stands back, measures up what is before it, gropes towards its limits, stumbles against what it does not mean, and digs pits to mark out its own path.' His discourse also '... open[s] up underground passages, ... finding overhangs that reduce and deform its itinerary.' (p. 17.) The subject of Lauer looms to presence in our reading of Foucault, as a metaphor for the archaeological project with respect to the subject of architecture. Theory, Foucault demands, should not be ' ... secretly ... related to the synthetic activity of the subject, ... the sovereignty of consciousness,' (p. 14,) but instead it should concern itself with ' ... the intrinsic description of monuments.' (p. 7.) We (Lauer) (history) should not attempt to ' ... pierce through the density [of a monumental trace] in order to reach what remains silently interior to it,' but should acknowledge instead that everything that is found and reassembled is fragments of a former monument. The transcendental Subject, the 'god' of modern phenomenology, the mythical point of origin 
which secrets itself at the centre of a pyramid, which effectively repossesses everything to itself as objects of an idealised intentionality, turns the world to stone, is another monumental trace, a trace of modernity, a modern language game, and in particular it is the culmination and end in western history of the destining of idealising thinking. The task of criticism therefore is to free theory of architecture from subjection to the subject, to dispense with 'things', to 'de-presentify' them, and to deal with the archaeological traces of discourse as evidence of practices that once '... systematically form[ed] the objects of which they speak.' (pp. 47-49.)

The two sets of readings of the petrification of the Subject, archaic and modern, which we have had space here only to indicate in their barest outlines ${ }^{21}$, are neither of them right nor wrong in themselves. The first, the gathering into stone and bearing up of a metaphorising thinking of cosmos, may or may not be more truly original or even representative at all of the archaic intentions of the pyramid builders. And the second reading, the modern nihilistic interpretation of a gathering of technology, a stony place, like a quarry, a site of no intrinsic significance, 'from which the gods have fled,' may be no less 'true' for disclaiming 'originality'. Every reading comprises its own meaning. But architecture can lay claim to autonomous meaning only when diverse and even contradictory readings are, not united, but allowed to co-exist, to dwell together in the figure of a word-play, a pun, in the structure of a metaphor, in the house of language. In philosophy Heidegger and Vattimo have called this event of critical revision of language Verwindung, 'overcoming', or 'recovering', a form of disclosure of meaning that is not a dialectical schism, a progress of logical disputation, but that is not at all the overthrowing and rejection of idealising thinking as such either. The difference between these readings of architecture, modern and archaic, is not a difference between idealising thinking and metaphorising thinking, for both sets of readings are metaphorical. The different readings reveal, not the superiority or inferiority of one or the other, not the falsification of true architectural facts, not the logical error, either in ancient or modern ways 
of thinking about an architectural object, but what is revealed is a turning [Einkehr] in the historical path of metaphorising thinking about architecture, a doubling back of reading that is in fact recuperative and proper in a theory of architecture. For architectural metaphor has the character of destining. Duplicity itself, recovering itself, turning itself, but not refutation, is a proper property, a hallmark of a theory of architecture. Heidegger remarks:

'That which has the character of destining moves, in itself, at any given time, toward a special moment that sends it into another destining, in which, however, it is not simply submerged and lost. We are still too inexperienced and thoughtless to think the essence of the historical from out of destining and ordaining and taking place so as to adapt. We are still too easily inclined, out of habit, to conceive that which has the character of destining in terms of happening, and to represent the latter as an expiration, a passing away, of events that have been established historiographically. We locate history in the realm of happening, instead of thinking history in accordance with its essential origin from out of destining. But destining is essentially destining of Being, indeed ... Being itself ... changes in the manner of its destining. ${ }^{22}$

What Imhotep really constructed when he built the first proto-pyramid, was something more remarkable than either a house for a god or a colossal piling up of stone, more permanent and pervasive than any single architectural object or happening can possibly be. It was most simply a metaphor in stone, but a metaphor that became for a very long period of time the figure of civilised architecture. I have attempted to trace what Heidegger has called the 'special moment' in the destining of Imhotep stone, its turning from the era in which possible readings of it are archaic to the era of modernity, to trace the Geschichte of an architecture through reading the destining of its metaphors.

Petrification of the Subject can appear to be a figure of irreconcilable duplicity. Its various readings ancient and modern cannot be reconciled within the dualism intrinsic to western philosophy - as human subjectivity cannot be reconciled to the foundational objectivity of stone. And in terms of history and the politics of death the intersubjective relationship between Imhotep and Djoser cannot be reconciled with more recent architectural relation- 
ships, for instance of André Le Nôtre and Louis XIV, or of Hitler and Albert Speer, which latter are more immediately petrifying-in the sense that petrification connotes terror. The petrification of the Subject is however completely reconciled in architecture in the metaphorical figure of Imhotep stone-provided that architecture is rigorously theorised in terms of metaphor.

Notes:

An essential character of modern technology, according to Heidegger, is the aspect of unhiddenness, that modern materials reveal their idea and eidos from beginning to end of the processes of 'destining'. 'Natural' materials, by contrast, like stone, will always hide some reserve of nature, something which continues to call upon the 'techniques of the handcraftsman.' And this is because the geological origins of stone are hidden from the idealisation of technology, prior to the processes of mechanisation. The variable and unpredictable qualities 'of the earth' can never be completely eradicated from building stone. This is a sense in which the modern technologically constituted materials are understood to be 'honest', and stone reveals itself to be 'dis-honest'. M. Heidegger, The Question Concerning Technology and Other Essays, Trans. W. Lovitt (New York and London: Garland Publishing, 1977), pp. 13-14.

In Egypt in the Old Kingdom, this lexicographical connection of 'house' and 'stone' does not appear. $\mathrm{Pr}$, one word for 'house', for example, also meant 'estate' and 'garden'. 'In the reign of Snefru, Metjin built a pr, 200 cubits in length and 200 cubits in width ... a very large lake being constructed in it, and figs and grapes planted.' P. Spencer, The Egyptian Temple: A Lexicographical Study, (London: Kegan Paul International, 1984). The glyphs which represented 'funerary temple', 'heb-sed court', and 'house' were such that, were they translated into architectural language, they would represent or approximate 'plans' rather than 'elevations'. The glyphs for 'shrine', 'tenon-topped column', and 'papyriform column', by contrast, which is to say, figures of stone architecture, were represented in 'elevation'. In texts written after the pyramid age, 'pyramid' was glyphed as a triangle rather than a square, indicating it too was 'elevated' rather than 'planned'.

The architectural master-work of Imhotep has been unearthed (literally and physically) through years of dedicated archaeological research and fastidious architectural reconstruction by Lauer and co-workers. But large parts of the complex still remain buried beneath the sand. J.-P. Lauer, Saqqara, (London: Thames \& Hudson, 1976); C. Aldred, Egyptian Art (London: Thames and Hudson, 1980). 
Heidegger (M. Heidegger, The Piety of Thinking, Trans. J. G. Hart and J. C. Maraldo, (Bloomington and London: Indiana University Press, 1976)) identifies the essence of (idealising) thinking with the Hegelian Dialectic. 'Hegel's Logic ... made visible the richer truth of the laws of thought now returned to their foundations ...' (p. 51.) These 'laws of thought' which are made visible by Hegel at the foundations of idealising thinking, include: principles of identity, of contradiction, and of the excluded middle. The principle of excluded middle exacts: either $\mathrm{X}$ is $\mathrm{A}$ or $\mathrm{X}$ is not $\mathrm{A}$ ( $\mathrm{p}$. 46.) Hegel was not the first to formulate these laws of thought, but by the dialectical method he showed their finitude. For to expose rules at the logical foundations of idealising thinking is equally to deconstruct its claim to absolute and universal dominance. The foundation rules themselves disclose that other modes of thinking, by other sets of foundational rules, are equally possible. We can now, Heidegger writes, 'acknowledge another thinking as strange and listen to it as estranging in its abundant strangeness.' (p. 58.) For example, a 'rule' of metaphorising thinking, which Ricoeur exacts, (P. Ricoeur, The Rule of Metaphor, trans. R. Czerny (Toronto and Buffalo: University of Toronto Press, 1977),) specifically contradicts the principle of excluded middle. Ricoeur notes that '.. the 'place' of metaphor, its most inti-

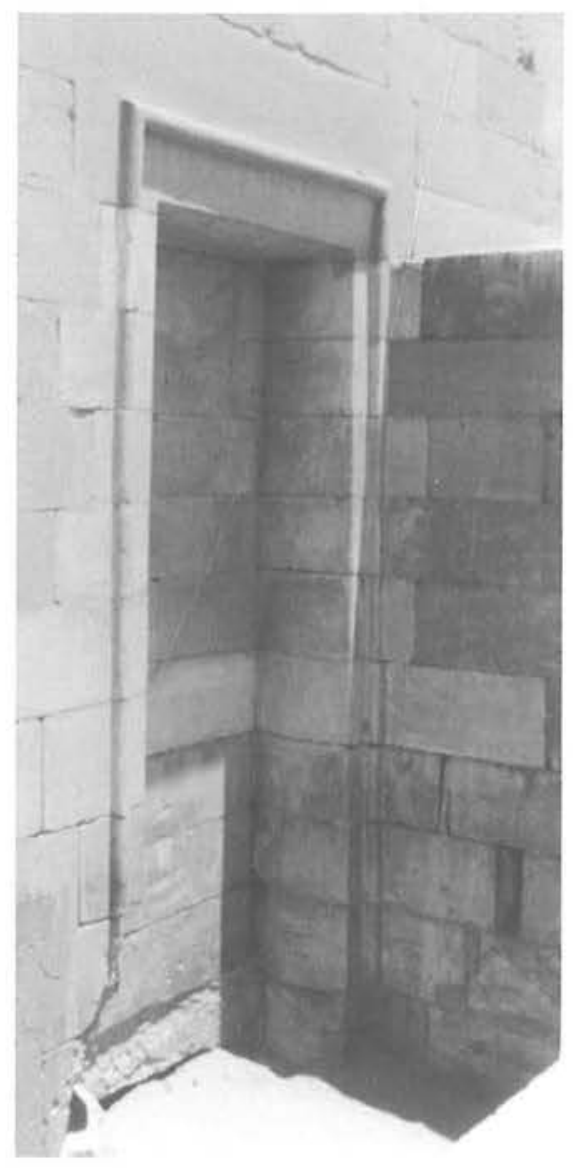
mate and ultimate abode, is ... the copula of the verb to be. The metaphorical 'is' at once signifies both 'is not' and 'is like.' If this is really so, we are allowed to speak of metaphorical truth ...' (p. 7.) In the duplicitous logic of metaphorising thinking, it can properly be said, as if one were relating a fictional narrative: 'It is and it is not so.' Derrida expresses this rule of metaphorising thinking in almost identical terms when he writes: "Because" and "although" at the same time, that's the logical form of the tension which makes all this thinking hum.' J. Derrida, Of Spirit, trans. G. Berrington and R. Bowlby (Chicago and London: Chicago University Press, 1989), p. 108. But the edificatory task, to reveal the complete double-logical 'rules of truth' of metaphorising thinking, has hardly yet begun. 
pp. 7-22. Also M. Wigley, Doctoral Thesis, University of Auckland, (1986).

Heidegger, (1977), p. 20.

'... ambiguousness, taken as a whole, becomes one side of a greater issue, whose other side is determined by poetry's innermost site.' M. Heidegger, On the Way to Language, trans. P. D. Hertz (New York: Harper \& Row, 1971), p. 192.

G. Vattimo, Verwindung: Nihilism and the postmodern in philosophy, Substance, Vol. XVI, No. 2, (1987), pp. 7-17.

Ibid.

Herodotus, The Histories, trans. A. de Sélincourt (Harmondsworth: Penguin, 1954), p. 158, remarks that in 'three hundred and forty-one generations' of history recorded by the Egyptian priesthood, 'no god ever assumed human form.'

Heidegger writes: 'The essence of technology starts man upon the way of that revealing through which the real everywhere, more or less distinctly, becomes standing-reserve. ... We shall call that sending-that-gathers which first starts man on the way to revealing, destining [Geschick].' The first pyramid is here read in the Heideggerian language as an 'original' site of a destining metaphor for technology, as an 'objectifying representation that makes the historical accessible as an object ... .' In its 'mode of revealing' as technology, the house of stone 'has its standing only from the ordering of the orderable.' Heidegger, (1977), pp. 13-24.

G. L. Ebersole, (Ritual Poetry and the Politics of Death in Early Japan, (Princeton: Princeton University Press, 1989),) in a seminal study, notes a number of points concerning the politics of death in early Japan that have their parallel in the Egypt of the time of Imhotep. He notes that structural fixity was not a characteristic of early societies in the period before the written word had yet firmly established and consolidated its authority as 'the' historical text. At the time of the death of the sovereign, apparently fixed structures of society could be deliberately put at risk, subjected to re-valuation and to political manipulation. Like Japan in the 7th Century BC, Egypt too, during the Third Dynasty, was only beginning to acquire a written language. In the mythistory of Egypt, Imhotep was not only an architect and the name for a kind of building stone-he was also the patron of scribes, and the 'inventor' of writing. (See J. B. Hurry, Imhotep, (London: Oxford University Press, 1928).) Whereas Japan 'borrowed' the art of writing from China, it is probable that Egypt also borrowed at least the rudiments of writing from Mesopotamia. One of the first books written in Japan, the Nihonshoki was of a piece with 'a strategy to legitimate the power, position and prestige of the imperial family,' through embroidering and supplementing the narrative of tama. The Pyramid Texts in Egypt ought to be interpreted in this light also, as part of a re-narration of mythistory in the interests of orderly succession. 
Passages from the Pyramid Texts which follow are quoted from translations provided in J. P. Allen, The cosmology of the Pyramid Texts, Yale Egyptological Studies, Vol. 3 (1989), pp. 1-28.

A. Fakhry, The Pyramids, 2nd Ed., (Chicago: University of Chicago Press, 1969), p 38.

I am quoting here from J. Derrida, The pit and the pyramid, in Margins of Philosophy, trans. A. Bass (Brighton: Harvester Press, 1982), pp. 69-108.

Derrida, (1982). Press, 1973), p. 137.

Derrida, (1982). of the pyramids, I.A.P.S. 11th Conference Proceedings, Culture Space History, Middle Eastern Technical University, Ankara, (1990).

Heidegger (1977), p. 39. 